\title{
Marketable yield of onion under different irrigation depths, with and without mulch
}

\author{
Daniel F. de Carvalho ${ }^{1}$, Eduardo C. Ribeiro ${ }^{2} \&$ Daniela P. Gomes ${ }^{1}$ \\ ${ }^{1}$ Universidade Federal Rural do Rio de Janeiro/Instituto de Tecnologia/Departamento de Engenharia. Seropédica, RJ. E-mail: carvalho@ufrrj.br \\ (Corresponding author); danielagomesagro@hotmail.com \\ ${ }^{2}$ Instituto Federal de Educação Ciência e Tecnologia do Tocantins/Campus Avançado Pedro Afonso/Coordenação dos Cursos Técnicos em Agropecuária. \\ Pedro Afonso. TO. E-mail: eduardo.ribeiro@ifto.edu.br
}

\section{Key words:}

crop coefficient water requirement Allium cepa L. vegetable grass residues

\begin{abstract}
A B S T R A C T
The objectives of this study were to obtain the onion crop coefficients and evaluate the influence of different irrigation depths $(0,22,45,75$ and $100 \%$ of crop evapotranspiration) on marketable yield and quality of onion bulbs cultivated with and without mulch of elephant grass. The experiment was carried out in Seropédica, RJ, Brazil, from May to September 2012, in a Red Yellow Argisol. The experimental design was in randomized blocks in split plots, with 10 treatments and seven replicates. Irrigation management was performed through soil water balance using the Time Domain Reflectometry technique, with probes installed horizontally at 7.5 and $22.5 \mathrm{~cm}$ depths. The use of mulch allowed the application of smaller irrigation depths, leading to lower crop coefficient (18\% in stage II and $3 \%$ in stage III) in comparison to the crop without mulch. Irrigation depths associated with the use of mulch influenced the evaluated production variables, proving to be an alternative to increase marketable yield and quality of onion bulbs, with lower irrigation depth.
\end{abstract}

\section{Palavras-chave:}

coeficiente de cultivo necessidade hídrica Allium cepa L. resíduos vegetais de gramíneas

\section{Produtividade comercial da cebola sob diferentes lâminas de irrigação, com e sem cobertura do solo}

\section{R E S U M O}

Objetivou-se neste estudo obter os coeficientes de cultivo para a cultura da cebola e avaliar a influência de diferentes lâminas de irrigação $(0,22,45,75$ e 100\% da evapotranspiração da cultura) na produtividade comercial e na qualidade de bulbos de cebola, cultivada com e sem cobertura vegetal morta de capim-elefante no solo. O experimento foi realizado em Seropédica, RJ, Brasil, entre maio e setembro de 2012, em um Argissolo VermelhoAmarelo. O delineamento experimental adotado foi em blocos casualizados em parcelas subdivididas, com10 tratamentos e sete repetições. O manejo da irrigação foi realizado por meio do balanço de água no solo utilizando a técnica da Reflectometria no Domínio do Tempo, a partir de sondas instaladas horizontalmente a 7,5 e 22,5 cm de profundidade. A utilização da cobertura morta permitiu a aplicação de menores lâminas de irrigação, proporcionando coeficientes de cultivo inferiores (18\% no estágio II e $3 \%$ no estágio III) ao cultivo sem cobertura do solo. A lâmina de irrigação associada ao uso da cobertura vegetal morta no solo influenciou as variáveis de produção avaliadas, demonstrando ser uma alternativa para elevar a produtividade comercial e a qualidade de bulbos de cebola com menor lâmina de irrigação. 


\section{INTRODUCTION}

Onion (Allium cepa L.) stands out among the other cultivated vegetables, for its volume of production and consumption and economic value (Oliveira et al., 2013). In 2015 , an area of 56.4 thousand hectares was harvested in Brazil, generating a production of 1.42 million tons (IBGE, 2016).

Onion cultivation is normally conducted under irrigation, which is considered an essential instrument to increase its yield, if carried out according to technical criteria. While the mean national production is approximately $16 \mathrm{tha}^{-1}$, irrigated plantations show yield higher than $25 \mathrm{t} \mathrm{ha}^{-1}$ (Marouelli et al., 2005). In general, the knowledge on the total water demand by the crop alone does not guarantee an efficient irrigation management, thus requiring the application of water according to crop water demands in each phenological stage or phase (Souza et al., 2011). Crop water demand (crop evapotranspiration - ETc) is normally estimated using information on reference evapotranspiration (ETo) (Zanetti et al., 2008) and crop coefficient (Kc) appropriate for each crop and climatic condition.

Organic agriculture is a cultivation system that has gained social, political and scientific recognition worldwide because it is based on the application of agroecological strategies, using local inputs, increasing the added value of the products and promoting a fairer marketing chain (Ríos et al., 2016). The use of mulch, a common practice in this cultivation system, reduces the natural water losses through evaporation on soil surface, thus leading to an increment in water productivity by the crop (Carvalho et al., 2011).

Given the above, this study aimed to estimate crop coefficients $(\mathrm{Kc})$ for onion in organic cultivation, with and without grass mulch on the soil, and evaluate the effect of different irrigation depths and mulching on the marketable yield and quality of onion bulbs.

\section{Material AND Methods}

The experiment was carried out from May to September 2012, in the Agroecological Production Integrated System (SIPA), in Seropédica, RJ, Brazil ( $22^{\circ} 48^{\prime}$ S; $43^{\circ} 41^{\prime} \mathrm{W} ; 33 \mathrm{~m}$ ). The soil of the studied area was classified as moderate-A dystrophic Red Yellow Argisol, with sandy loam texture (EMBRAPA, 2006). A weather station installed in the experimental area provided the mean values of air temperature, relative humidity, wind speed, solar radiation and rainfall, for the different crop growth stages (Table 1).

Table 1. Mean air temperature $(\mathrm{Tm})$, mean relative air humidity $(\mathrm{RH})$, wind speed $\left(\mathrm{U}_{2}\right)$, global solar radiation $(\mathrm{Rs})$ and rainfall for the different crop growth stages

\begin{tabular}{|c|c|c|c|c|c|}
\hline Stage & $\begin{array}{l}\text { Tm } \\
\left({ }^{\circ} \mathrm{C}\right)\end{array}$ & $\begin{array}{l}\text { RH } \\
(\%)\end{array}$ & $\begin{array}{c}\mathrm{U}_{2} \\
\left(\mathrm{~m} \mathrm{~s}^{-1}\right)\end{array}$ & $\begin{array}{c}\text { Rs } \\
\left(\mathrm{MJ} \mathrm{m}^{-2} \mathrm{~d}^{-1}\right)\end{array}$ & $\begin{array}{c}\text { Rainfall } \\
(\mathrm{mm})\end{array}$ \\
\hline$\left.\right|^{*}$ & 21.9 & 76.9 & 0.74 & 11.66 & 49.0 \\
\hline$\|^{* *}$ & 20.4 & 74.6 & 0.82 & 12.13 & 81.4 \\
\hline$\|||^{\star \star * \star}$ & 20.9 & 69.5 & 1.08 & 17.38 & 24.7 \\
\hline $\mathrm{IV} * * \star \star$ & 23.3 & 67.9 & 1.52 & 15.89 & 62.6 \\
\hline
\end{tabular}

* I - From seedling transplantation to initial establishment of plants; ** II - From initia establishment to beginning of bulb formation; ${ }^{\star \star *} \mathrm{III}$ - Beginning of bulb formation to beginning of maturation; ${ }^{\star \star \star \star *}$ IV - Beginning of bulb maturation to harvest
The onion cultivar 'Alfa Tropical' was sown on 288cell polystyrene trays, maintained in a greenhouse and daily irrigated. After 40 days from sowing, seedlings were transplanted at spacing of $0.25 \mathrm{~m}$ between rows and $0.1 \mathrm{~m}$ between plants. Weeds were controlled through manual weeding at 15, 40 and 70 days after transplantation (DAT). Fertilization at planting was performed using bovine manure at dose of $25 \mathrm{t} \mathrm{ha}^{-1}$. Top-dressing fertilization used $100 \mathrm{~kg} \mathrm{ha}^{-1}$ of $\mathrm{N}$, split into two applications (30 and $50 \mathrm{DAT}$ ), in the form of castor bean cake. At 124 DAT, plants were harvested and maintained for 15 days in the shade (curing period).

The experimental design was randomized blocks in split plots, with 10 treatments and 7 replicates (Figure 1). Treatments consisted of five irrigation depths (plots), corresponding to 0 (L0), 22 (L1), 45 (L2), 75 (L3) and 100\% (L4) of crop evapotranspiration $(\mathrm{ETC})$ and the use of mulch on the soil: absence of mulch (AM) and presence of mulch (PM) (subplots). Subplots were composed of 4 planting rows with length of $1.0 \mathrm{~m}$, considering the 20 plants from the central rows for evaluation.

During the period of seedling establishment in the field, the experiment was irrigated using a conventional sprinkler system and irrigation depth was estimated by Class A pan evaporation, adopting tank coefficient (Kp) of 0.8 (Carvalho et al., 2006) and crop coefficient (Kc) of 1.0 (Marouelli et al., 2005). From 23 DAT on, seedlings were irrigated by drip irrigation, using two lateral lines per bed, with actual flow rates of 2.4 (L1), 4.9 (L2), 8.1 (L3) and $10.8 \mathrm{~L} \mathrm{~h}^{-1}$ (L4) (water depth applied by the treatments), promoting distribution uniformity coefficients above $95 \%$.

Irrigation management was performed using the Time Domain Reflectometry (TDR) technique (Soncela et al., 2013), by monitoring soil water content in the 14 subplots corresponding to the water depth L4 (100\% ETc). For adequate use of TDR, the device was previously calibrated in the studied area, according to Carvalho et al. (2011), and the soil moisture corresponding to field capacity was determined in the $0-0.15 \mathrm{~m}$ layer $\left(0.214 \mathrm{~cm}^{3} \mathrm{~cm}^{-3}\right)$. Readings of apparent dielectric constant (Ka), obtained through TDR probes, were taken every two days, immediately before irrigations and for both soil cover conditions. The probes were composed of three parallel stainless-steel rods spaced by $0.015 \mathrm{~m}$, with diameters of $0.003 \mathrm{~m}$ and length of $0.18 \mathrm{~m}$. In total, $28 \mathrm{TDR}$ probes were installed horizontally at depths of 7.5 and $22.5 \mathrm{~cm}$, in the subplots with and without mulch.

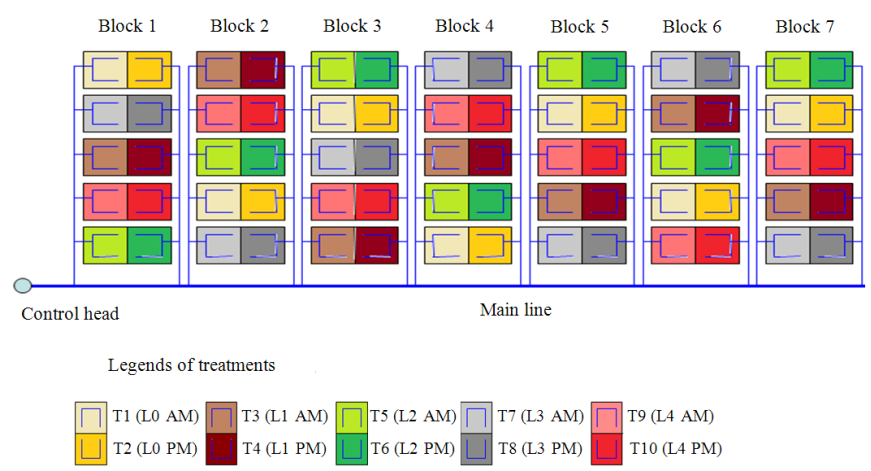

Figure 1. Scheme of the adopted experimental design 
Besides the water depths applied during the establishment period and by the treatments, effective rainfall (Pef) was quantified, considered as the precipitated water depth $(\mathrm{mm})$ that increased water content in the plots to the soil moisture corresponding to field capacity (Carvalho et al., 2011).

After the period of seedling acclimation, crop evapotranspiration (ETc) was estimated through soil water balance (Andrade et al., 2014), which divided by reference evapotranspiration (ETo), obtained through FAO-56 PenmanMonteith method (Allen et al., 1998), allowed to determine Kc in different crop growth stages, as follows: I (from seedling transplantation to initial establishment of plants); II (from initial establishment to beginning of bulb formation); III (from beginning of bulb formation to beginning of maturation); and IV (from beginning of bulb maturation to harvest).

Mulch consisted of straw of elephant grasss (Pennisetum purpureum Schum, $c v$. Cameron) shoots, chopped and dried in the shade, at dose of $2.5 \mathrm{~kg} \mathrm{~m}^{-2}$ of dry matter (Oliveira et al., 2008), placed on the soil at 22 DAT.

The evaluated production variables were marketable yield bulbs with diameter greater than $35 \mathrm{~mm}\left(\mathrm{t} \mathrm{ha}^{-1}\right)$, mean diameter of marketable bulbs ( $\mathrm{mm}$ ) and percentage of bulbs in the classes established by CEAGESP (2001) (Table 2).

The data were subjected to analysis of variance and, when significant by the F test, the factor water depth was subjected to regression analysis at 5\% significance level.

Table 2. Classification of onion bulbs according to diameter

\begin{tabular}{cc}
\hline Class (C) & Diameter (mm) \\
C1 & $\geq 35$ \\
C2 & $35<D \leq 50$ \\
C3 & $50<D \leq 60$ \\
C4 & $60<D \leq 70$ \\
C5 & $70<D \leq 90$ \\
\hline
\end{tabular}

\section{Results AND Discussion}

The irrigation depths corresponding to $0,22,45,75$ and $100 \%$ ETc applied in the treatments AM and PM were equal to $0,155.0,220.6,320.5$ and $372.7 \mathrm{~mm}$, and $0,145.5,207.6$, 285.0 and $351.4 \mathrm{~mm}$, respectively. The data of estimated ETo, ETc and crop coefficient $(\mathrm{Kc})$ calculated for both soil cover conditions are presented in Table 3.

The highest Kc values were obtained in stage III, when the crop demands greater volume of water due to the formation
Table 3. Reference evapotranspiration (ETo), crop evapotranspiration (ETC) and crop coefficient $(\mathrm{KC})$ in the different growth stages of onion, in the presence (PM) and absence (AM) of mulch

\begin{tabular}{|c|c|c|c|c|c|c|}
\hline \multirow{3}{*}{ Stage } & \multirow{3}{*}{$\begin{array}{c}\text { Duration } \\
\text { (days) }\end{array}$} & \multirow{3}{*}{$\begin{array}{l}\text { ETo } \\
(\mathrm{mm})\end{array}$} & \multicolumn{4}{|c|}{ Soil cover } \\
\hline & & & AM & PM & AM & PM \\
\hline & & & \multicolumn{2}{|c|}{ ETc (mm) } & \multicolumn{2}{|c|}{ Kc } \\
\hline I & $21^{*}$ & 36.3 & 65.7 & 65.7 & $1.0^{* *}$ & $1.0^{\star *}$ \\
\hline II & 37 & 75.9 & 73.0 & 60.7 & 0.8 & 0.6 \\
\hline III & 45 & 137.7 & 164.7 & 159.6 & 1.0 & 1.0 \\
\hline IV & 21 & 77.6 & 69.3 & 65.3 & 0.8 & 0.7 \\
\hline
\end{tabular}

* Beginning with seedling transplantation; ${ }^{* \star} \mathrm{Kc}$ previously fixed for stage I due to the use of acclimation irrigations with fixed interval of 1 day, as recommended by Costa et al. (2002) and Marouelli et al. (2005)

of bulbs. Similar responses were reported by Marouelli et al. (2005) and Oliveira et al. (2013), who observed this same trend. In the present study, the use of mulch, which according to Marouelli et al. (2005) decreases soil exposure to evaporation, promoted lower Kc values, with reductions of $18 \%$ in stage II and $3 \%$ in stage IV, compared with the AM (Table 3). Oliveira Neto et al. (2011) also found lower Kc values for the beet crop, using mulch of elephant grass, compared with the treatment without mulch, and these differences were equal to 61.8 , 33.1 and $33.3 \%$, for the initial, intermediate and final stages, respectively. The variation found in the results of Kc confirms the importance of conducting field tests to determine the water demand of various crops in different environments and management conditions (Doorenbos \& Pruitt, 1977; Allen et al., 1998).

Marketable yield (Figure 2A) and marketable mean diameter (Figure 2B) of onion bulbs were influenced by the irrigation depths, under both soil cover conditions. The highest marketable yields (42 $\mathrm{t} \mathrm{ha}^{-1}$ without mulch and $56 \mathrm{t} \mathrm{ha}^{-1}$ with mulch) were obtained with water depth corresponding to $100 \%$ ETc. Bandeira et al. (2013) also obtained highest marketable yield of onion bulbs applying water depth corresponding to $100 \% \mathrm{ETc}$, compared with $75 \%$ ETc, performing irrigation management with Class A pan and without using mulch. Similar effect of different irrigation depths on onion bulb yield have also been observed by Olalla et al. (2004), Enciso et al. (2009), Ramalan et al. (2010) and Igbadun et al. (2012).

Kumar et al. (2007) demonstrated that a greater water comfort to the onion crop is obtained when the soil is maintained close to field capacity (100\% ETc), promoting
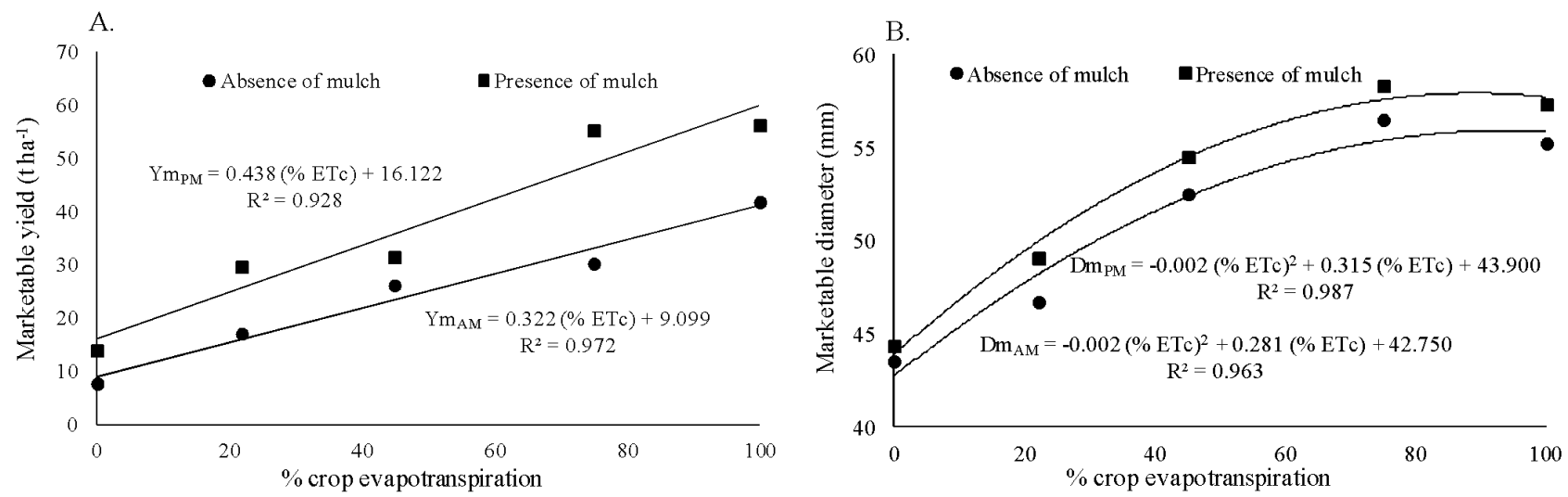

Figure 2. Marketable yield (A) and marketable mean diameter (B) of onion bulbs as a function of irrigation depths, in the presence $(P M)$ and absence $(A M)$ of mulch 
maximum values of marketable yield. Water replacement to the soil lower than $100 \%$ ETc causes the crop to use more energy in water absorption, thus not using it for bulb filling (Rajput \& Patel, 2006).

Cultivation in covered soil with replacement of about $58.9 \%$ ETc (approximately $207 \mathrm{~mm}$ ) led to marketable bulb yield (42.0 $\mathrm{t} \mathrm{ha}^{-1}$ ) similar to that obtained in the cultivation in exposed soil with the application of $100 \%$ ETc $(372.7 \mathrm{~mm})$ (Figure $2 \mathrm{~A})$.

The highest values of marketable mean diameter $(56.5 \mathrm{~mm}$ without mulch and 58.4 with mulch) were obtained with the application of water depths corresponding to $75 \%$ ETc (Figure $2 \mathrm{~B}$ ), and were considered as acceptable by the consumers for organic cultivation (Araújo et al., 2004).

Irrigation depths influenced the percentages of bulbs in the classes C1, C3, C4 and C5, regardless of the use of mulch (Figures 3A, C, D and E). However, the percentage of bulbs in the $\mathrm{C} 2$ class was only influenced by the irrigation depths when mulch was used (Figure 3B).
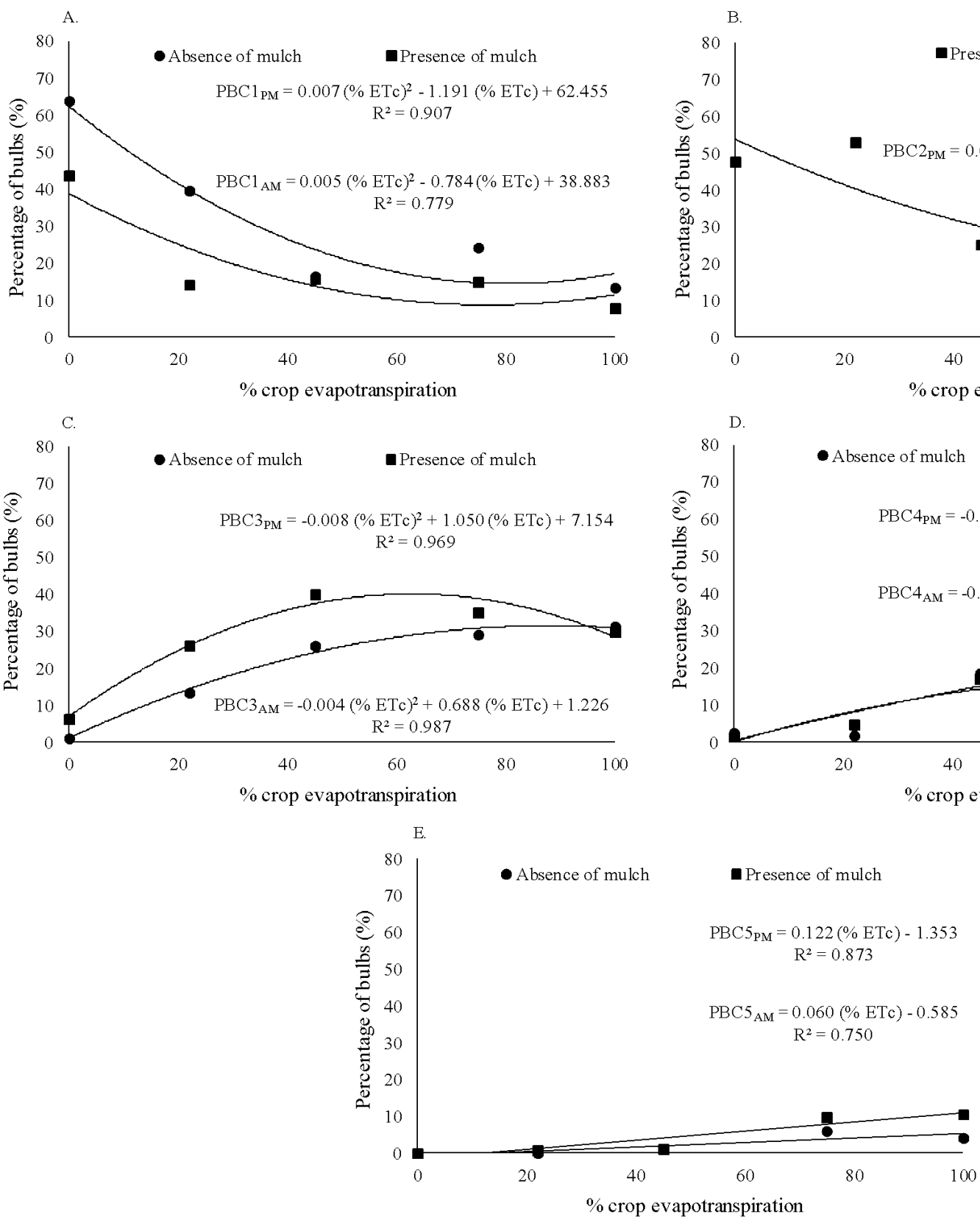

Figure 3. Percentage of onion bulbs (PB) in the classes $C 1(A), C 2(B), C 3(C), C 4(D)$ and $C 5(E)$ as a function of the irrigation depths, in the presence (PM) and absence (AM) of mulch

The percentages of unmarketable bulbs (C1) and $\mathrm{C} 2$ bulbs were higher with the applications of irrigation depths corresponding to 0 and $22 \%$ ETc, respectively, and lower with the application of irrigation depths corresponding to 75 and $100 \%$ ETc, respectively, with and without mulch (Figure $3 \mathrm{~A}$ and $\mathrm{B})$. The percentage of bulbs in the $\mathrm{C} 3$ class was lower with the application of irrigation depths corresponding to 0 and $22 \%$ ETc, reaching maximum values of $32 \%$ without mulch and $40 \%$ with mulch, respectively, at water depths corresponding to 100 and $45 \%$ ETc (Figure 3C).

The highest percentage of bulbs in the C4 class was found with the application of irrigation depths corresponding to $45 \%$ ETc, without mulch, and to $100 \%$ ETc, with mulch. Irrigation depths corresponding to $75 \%$ ETc, without mulch, and $100 \%$ ETc, with mulch, were responsible for the higher percentage of bulbs in the C5 class (Figures 3D and E).

These results show that the application of lower irrigation depths led to higher onion bulbs classified as C1 and C2 and
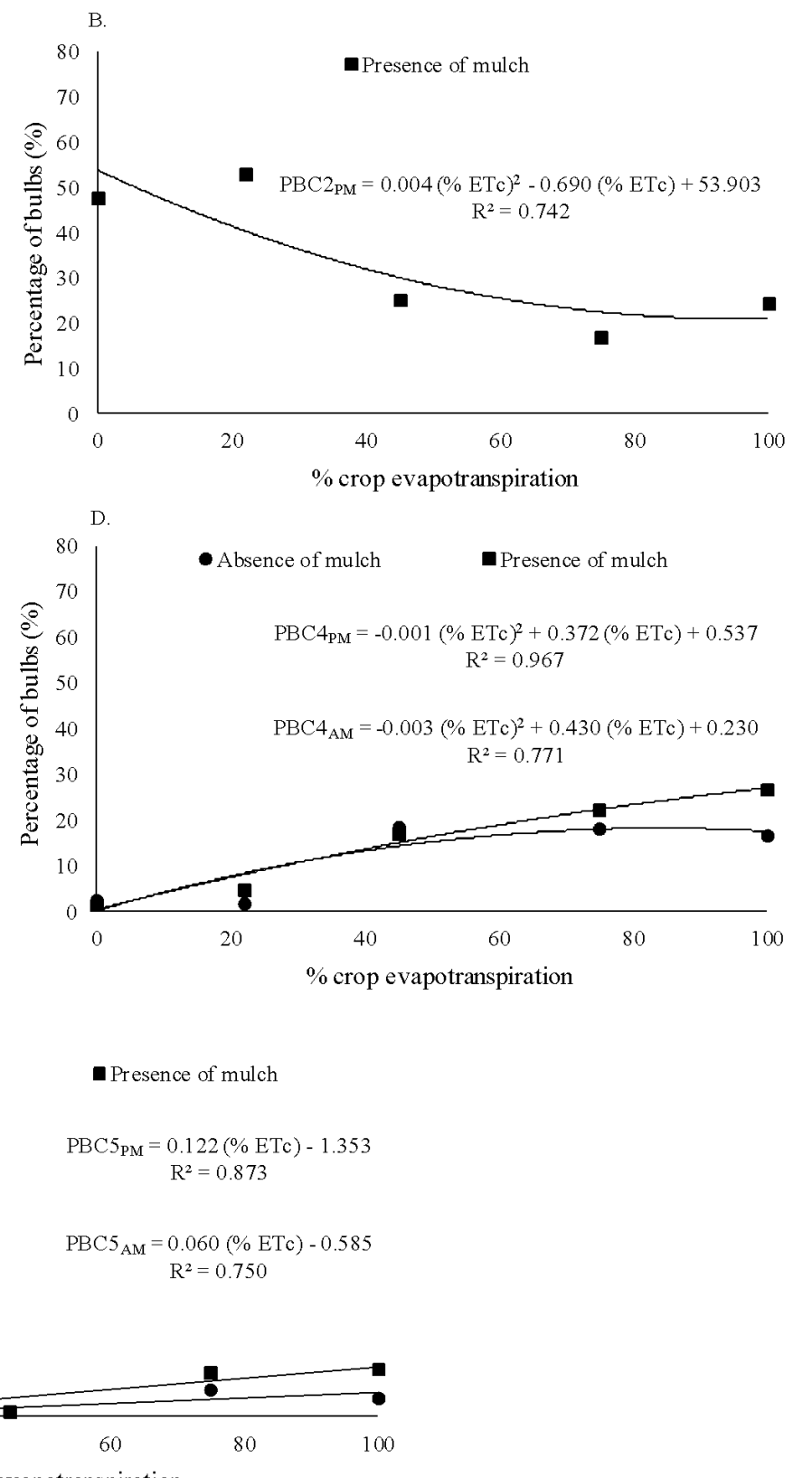
Table 4. Marketable yield (MY), marketable mean diameter (MMD) and percentage of onion bulbs in the different diameter classes in the presence (PM) and absence (AM) of mulch

\begin{tabular}{|c|c|c|c|c|c|c|c|}
\hline \multirow{2}{*}{\multicolumn{2}{|c|}{ Evaluated variables }} & \multirow{3}{*}{$\begin{array}{c}\text { Mulching } \\
\text { AM }\end{array}$} & \multicolumn{5}{|c|}{$\%$ ETC } \\
\hline & & & 0 & 22 & 45 & 75 & 100 \\
\hline \multirow{2}{*}{ Marketable yield } & \multirow{2}{*}{$\left(\mathrm{t} \mathrm{ha}^{-1}\right)$} & & $7.6 \mathrm{a}$ & $17.1 \mathrm{a}$ & $26.3 a$ & $30.4 b$ & $32.0 \mathrm{~b}$ \\
\hline & & PM & $14.0 \mathrm{a}$ & $30.0 \mathrm{a}$ & $31.4 \mathrm{a}$ & $55.5 \mathrm{a}$ & $56.2 a$ \\
\hline \multirow{2}{*}{ Marketable mean diameter } & \multirow{2}{*}{$(\mathrm{mm})$} & AM & $43.5 \mathrm{a}$ & $46.7 \mathrm{a}$ & $52.5 \mathrm{a}$ & $56.5 \mathrm{a}$ & $55.2 a$ \\
\hline & & PM & $44.4 \mathrm{a}$ & $49.1 \mathrm{a}$ & $54.5 \mathrm{a}$ & $58.4 a$ & $57.3 a$ \\
\hline \multirow{2}{*}{$C 1(\leq 35)$} & \multirow{10}{*}{$(\%)$} & AM & $64 a$ & $40 a$ & $17 a$ & $24 a$ & $13 a$ \\
\hline & & PM & $44 b$ & $14 b$ & $16 a$ & $15 a$ & $8 a$ \\
\hline \multirow{2}{*}{$\mathrm{C} 2(35<\mathrm{D} \leq 50)$} & & AM & $32 b$ & $44 a$ & $37 a$ & $22 a$ & $33 a$ \\
\hline & & PM & $48 a$ & $53 a$ & $25 a$ & $17 a$ & $24 a$ \\
\hline \multirow{2}{*}{$\mathrm{C} 3(50<\mathrm{D} \leq 60)$} & & AM & $1 \mathrm{a}$ & $14 \mathrm{~b}$ & $26 b$ & $29 a$ & $32 \mathrm{a}$ \\
\hline & & PM & $6 \mathrm{a}$ & $26 \mathrm{a}$ & $40 \mathrm{a}$ & $35 \mathrm{a}$ & $30 \mathrm{a}$ \\
\hline \multirow{2}{*}{$\mathrm{C} 4(60<\mathrm{D} \leq 70)$} & & AM & $3 a$ & $2 \mathrm{a}$ & 19a & $18 \mathrm{a}$ & $17 a$ \\
\hline & & PM & $2 a$ & $5 a$ & $17 a$ & $22 a$ & $27 a$ \\
\hline \multirow{2}{*}{$\mathrm{C} 5(70<\mathrm{D} \leq 90)$} & & AM & Oa & Oa & $1 \mathrm{a}$ & $6 a$ & $4 b$ \\
\hline & & PM & $0 \mathrm{a}$ & $1 \mathrm{a}$ & $1 \mathrm{a}$ & $10 \mathrm{a}$ & $11 a$ \\
\hline
\end{tabular}

Means followed by the same letter in the column do not differ significantly by $\mathrm{F}$ test at 0.05 probability level

that the application of higher irrigation depths led to greater production of bulbs in the classes $\mathrm{C} 4$ and $\mathrm{C} 5$. Lack of water reduces turgor pressure and, consequently, sap flow through the conducting vessels (Taiz \& Zeiger, 2009), tending to decrease cell elongation and, therefore, bulb growth and development. The results also demonstrate the effect of mulching on the production of bulbs classified as $\mathrm{C} 1$ and $\mathrm{C} 2$, and increase in the production of bulbs classified as $\mathrm{C} 4$ and $\mathrm{C} 5$. Hence, the application of water depth corresponding to $100 \%$ ETc associated with the use of mulch promotes increments in the marketable yield and quality of onion bulbs. Production of higher-class onion bulbs leads to higher commercial profitability and greater acceptance in the Brazilian market (Bandeira et al., 2013), considered by Reghin et al. (2006) as an indicator of the high production quality achieved.

Table 4 shows the values of marketable yield, marketable mean diameter and percentage of onion bulbs under both soil conditions, for the different irrigation depths. The use of mulch led to gains in marketable yield when irrigation depths corresponding to 75 and $100 \%$ ETc were used. This result indicates that the use of mulch becomes a promising alternative to obtain better yields with reduction in water consumption. Igbadun et al. (2012) also found gains in the marketable yield of onion using mulch of rice and black polyethylene plastic.

Marketable mean diameter was not influenced by the use of mulch (Table 4). However, the use of mulch decreased the percentage of bulbs in the $\mathrm{C} 1$ class (unmarketable), when irrigation depths corresponding to 0 and $22 \%$ ETc were applied. In the class $\mathrm{C} 2$, the use of mulch led to increase in the percentage of bulbs in the treatment without irrigation $(0 \%$ $\mathrm{ETc}$ ) and, in the $\mathrm{C} 3$ class, the use of mulch caused increments in the percentage of bulbs when irrigation depths corresponding to 22 and $45 \%$ ETc were applied. In the C5 class, mulching promoted higher percentage of bulbs when the irrigation depth corresponding to $100 \%$ ETc was applied (Table 4).

The obtained gains may be related to the sum of the possible beneficial effects of soil cover by plant residues, such as reduction of water evaporation from soil surface, maintenance of moisture and reduction in soil temperature (Santos et al., 2012), reduction in soil exposure to the direct impact of rain drops and increase of carbon stock in the soil (Loss et al., 2014), increase in water productivity (Mota et al., 2010), reduction in the incidence of weeds (Silva et al., 2009) and supply of nutrients to the soil (Carvalho et al., 2011). The use of other types of mulch compared with the treatment without mulch also proved to be efficient to increase onion yield, such as the straw of bamboo or gliricidia (Santos et al., 2012).

\section{Conclusions}

1. The use of mulch promoted reduction of water consumption in the production of onion bulbs, with decrease of $18 \%$ (stage II) and 3\% (stage III) in the Kc values, in comparison to those obtained without mulch.

2. Irrigation depth associated with the use of mulch on the soil influenced onion bulb yield and quality.

3. Cultivation in covered soil led to marketable yield of onion bulbs similar to that obtained in the cultivation in exposed soil $\left(42.0 \mathrm{t} \mathrm{ha}^{-1}\right)$ with a $41.1 \%$ lower irrigation depth $(207 \mathrm{~mm})$.

4. Application of higher irrigation depths promoted higher production of bulbs in the classes $\mathrm{C} 4$ and $\mathrm{C} 5$.

\section{Literature Cited}

Allen, R. G.; Pereira, L. S.; Raes, D.; Smith, M. Crop evapotranspiration: Guidelines for computing crop water requirements. Rome: FAO, 1998. 308p.

Andrade, I. P. de S.; Carvalho, D. F. de; Almeida, W. S. de; Silva, J. B. G.; Silva, L. D. B. da. Water requirement and yield of fig trees under different drip irrigation management. Engenharia Agrícola, v.34, p.17-27, 2014. http://dx.doi.org/10.1590/S0100-69162014000100003 Araújo, J. F.; Costa, N. D.; Lima, M. A. C. de; Pedreira, C. M.; Santos, C. dos; Leite, W. de M. Avaliação de genótipos de cebola em cultivo orgânico. Horticultura Brasileira, v.22, p.420-424, 2004.

Bandeira, G. R. L.; Queiroz, S. O. P. de; Aragão, C. A.; Costa, N. D.; Santos, C. A. F. Desempenho agronômico de cultivares de cebola sob diferentes manejos de irrigação no submédio São Francisco. Irriga, v.18, p.73-84, 2013. https://doi.org/10.15809/ irriga.2013v18n1p73

Carvalho, D. F. de; Oliveira Neto, D. H. de; Ribeiro, R. de. L. D.; Guerra, J. G. M.; Rouws, J. R. C. Manejo da irrigação associada a coberturas mortas vegetais no cultivo orgânico da beterraba. Engenharia Agrícola, v.31, p.269-277, 2011. https://doi.org/10.1590/S010069162011000200007 
Carvalho, D. F. de; Silva, L. D. B.; Folegatti. M. V.; Costa, J. R.; Cruz, F. A. Avaliação da evapotranspiração de referência na região de Seropédica-RJ utilizando lisímetro de pesagem. Revista Brasileira de Agrometeorologia, v.14, p.97-105, 2006.

CEAGESP - Companhia de Entrepostos e Armazéns Gerais de São Paulo. Classificação da cebola (Allium cepa L.). São Paulo: CEAGESP, 2001. 2p. Disponível em: <http://http://www.ceagesp.gov.br/wp-content/ uploads/2015/07/cebola.pdf> Acesso em: 24 Mar. 2017.

Costa, E. L. da; Marouelli, W. A.; Camboim Neto, L. de F.; Silva, W. L. C. Irrigação da cebola. Informe Agropecuário, v.23, p.57-66, 2002.

Doorenbos, J.; Pruitt, W. O. Guidelines for predicting crop water requirements. Rome: FAO, 1977. 156p.

EMBRAPA - Empresa Brasileira de Pesquisa Agropecuária. Sistema brasileiro de classificação de solos. 2.ed. Brasília: Embrapa; Rio de Janeiro: Embrapa, 2006. 312p.

Enciso, J.; Weidenfeld, B.; Jifon, J.; Nelson, S. Onion yield and quality response to two irrigation scheduling strategies. Scientia Horticulturae, v.120, p.301-305, 2009. https://doi.org/10.1016/j. scienta.2008.11.004

IBGE - Instituto Brasileiro de Geografia e Estatística. Confronto das safras de 2015 e 2016 (1. Área e 2. Produção). Brasília: CONAB, 2016. Disponível em: <http://www.ibge.gov.br/home/estatistica/ indicadores/agropecuaria/lspa/defaulttab.shtm $>$ Acesso em: 04 Ago. 2016.

Igbadun, H. E.; Ramalan, A. A.; Oiganji, E. Effects of regulated deficit irrigation and mulch on yield, water use and crop water productivity of onion in Samaru, Nigeria. Agricultural Water Management, v.109, p.162-169, 2012. https://doi.org/10.1016/j.agwat.2012.03.006

Kumar, S.; Imtiyaz, M.; Kumar, A.; Singh, R. Response of onion (Allium cepa L.) to different levels of irrigation water. Agricultural Water Management, v.89, p.161-166, 2007. https://doi.org/10.1016/j. agwat.2007.01.003

Loss, A.; Ribeiro, E. C.; Pereira, M. G.; Costa, E. M. Atributos físicos e químicos do solo em sistemas de consórcio e sucessão de lavoura, pastagem e silvipastoril em Santa Teresa, ES. Bioscience Journal, v.30, p.1347-1357, 2014.

Marouelli, W. A.; Costa, E. L.; Silva, H. R. Irrigação da cultura de cebola. Brasília: Embrapa, 2005. 17p.

Mota, J. C. A.; Libardi, P. L.; Brito, A. dos S.; Assis Júnior, R. N. de; Amaro Filho, J. Armazenagem de água e produtividade de meloeiro irrigado por gotejamento, com a superfície do solo coberta e desnuda. Revista Brasileira de Ciência do Solo, v.34, p.1721-1731, 2010. https://doi.org/10.1590/S0100-06832010000500024

Olalla, F. M. de S.; Domínguez-Padilla, A.; López, R. Production and quality of the onion crop (Allium cepa L.) cultivated under controlled deficit irrigation conditions in a semi-arid climate. Agricultural Water Management, v.68, p.77-89, 2004. https://doi. org/10.1016/j.agwat.2004.02.011

Oliveira, F. F. de; Guerra, J. G. M.; Almeida, D. L. de; Ribeiro, R. de L. D.; Espíndola, J. A. A.; Ricci, M. dos S. F.; Ceddia, M. B. Avaliação de coberturas mortas em cultura de alface sob manejo orgânico. Horticultura Brasileira, v.26, p.216-220, 2008. https:// doi.org/10.1590/S0102-05362008000200017
Oliveira, G. M. de; Leitão, M. M. V. B. R.; Bispo, R. de C.; Santos, I. M. S.; Lima, C. B. de A.; Carvalho, A. R. P de. Coeficiente de cultura e produtividade da cebola submetida a diferentes lâminas de irrigação. Revista Brasileira de Engenharia Agrícola e Ambiental, v.17, p.969-974, 2013. https://doi.org/10.1590/S141543662013000900009

Oliveira Neto, D. H.; Carvalho, D. F. de; Silva, L. D. B. da; Guerra, J. G. M.; Ceddia, M. B. Evapotranspiração e coeficientes de cultivo da beterraba orgânica sob cobertura morta de leguminosa e gramínea. Horticultura Brasileira, v.29, p.330-334, 2011. https:// doi.org/10.1590/S0102-05362011000300012

Rajput, T. B. S.; Patel, N. Water and nitrate movement in dripirrigated onion under fertigation and irrigation treatments. Agricultural Water Management, v.79, p.293-311, 2006. https:// doi.org/10.1016/j.agwat.2005.03.009

Ramalan, A. A.; Nega, H.; Oyebode, M. A. Effect of deficit irrigation and mulch on water use and yield of drip irrigated onions. WIT Transactions on Ecology and the Environment, v.134, p.39-50, 2010. https://doi.org/10.2495/SI100041

Reghin, M. Y.; Otto, R. F.; Olinik, J. R.; Jacoby, C. F. S. Produção de cebola sobre palhada a partir de mudas obtidas em bandejas com diferentes números de células. Horticultura Brasileira, v.24, p.414420, 2006. https://doi.org/10.1590/S0102-05362006000400004

Ríos, I. de los; Rivera, M.; García, C. Redefining rural prosperity through social learning in the cooperative sector: 25 years of experience from organic agriculture in Spain. Land Use Policy, v.54, p.85-94, 2016. https://doi.org/10.1016/j.landusepol.2016.02.009 Santos, S. da S.; Espíndola, J. A. A.; Guerra, J. G. M.; Leal, M. A. de A.; Ribeiro, R. de L. D. Produção de cebola orgânica em função do uso de cobertura morta e torta de mamona. Horticultura Brasileira, v.30, p.549-552, 2012. https://doi.org/10.1590/S010205362012000300032

Silva, A. C. da; Hirata, E. K.; Monquero, P. A. Produção de palha e supressão de plantas daninhas por plantas de cobertura, no plantio direto do tomateiro. Pesquisa Agropecuária Brasileira, v.44, p.2228, 2009. https://doi.org/10.1590/S0100-204X2009000100004

Soncela, R.; Sampaio, S. C.; Vilas Boas, M. A.; Tavares, M. H. F.; Smanhotto, A. Construction and calibration of TDR probes for volumetric water content estimation in a distroferric Red Latosol. Engenharia Agrícola, v.33, p.919-928, 2013. https://doi. org/10.1590/S0100-69162013000500004

Souza, A. P. de; Pereira, J. B. A.; Silva, L. D. B. da; Guerra, J. G. M.; Carvalho, D. F. de. Evapotranspiração, coeficientes de cultivo e eficiência do uso da água da cultura do pimentão em diferentes sistemas de cultivo. Acta Scientiarum. Agronomy, v.33, p.15-22, 2011. https://doi.org/10.4025/actasciagron.v33i1.5527

Taiz, L.; Zeiger, E. Fisiologia vegetal. Porto Alegre: Artmed, 2009. $819 \mathrm{p}$.

Zanetti, S. S.; Sousa, E. F.; Carvalho, D. F. de; Bernardo, S. Estimação da evapotranspiração de referência no estado do Rio de Janeiro usando redes neurais artificiais. Revista Brasileira de Engenharia Agrícola e Ambiental, v.12, p.174-180, 2008. https://doi. org/10.1590/S1415-43662008000200010 